\title{
THE IMPACTS OF ROBOTS AND ARTIFICIAL INTELLIGENCE ON SERVICE QUALITY IN THE HOTEL INDUSTRY
}

\author{
Suzana Marković ${ }^{1}$ \\ Sanja Raspor Janković \\ Vedran Zubović ${ }^{3}$ ii
}

Received: July 2, 2020 / Revised: September 3, 2020 / Accepted: November 18, 2020

(C) Association of Economists and Managers of the Balkans, 2020

\begin{abstract}
Service robots and artificial intelligence promise to improve the service quality. Robotics in combination with rapidly improving technologies like artificial intelligence, bring opportunities for a wide range of innovations that have the potential to change service quality in hotel industry. Based on an extensive literature review, this article presents the acceptance of service robots in hotel industry. The paper acknowledges that the adoption of the robots and artificial intelligence on service quality is focused on the challenges of technological characteristics, customers' readiness and practical effectiveness of the business. The study provides a comprehensive and systematic review of robots and AI concepts in a hotel industry and examines their impacts on service quality. The hotel industry future is going to be affected with high-tech tourism companies offering robot-automated services which rely on guidance to adopt and integrate robotics into their customer service operations.
\end{abstract}

Keywords: Robots, Service Quality (SQ), Artificial Intelligence (AI), Hotel Industry, Content Analysis.

\section{JEL Classification L84}

suzanam@fthm.hr

University of Rijeka, Faculty of Tourism and Hospitality Management, Primorska 42, 51410 Opatija, Croatia Polytechnic of Rijeka, Trpimirova 2, 51000 Rijeka, Croatia

University of Rijeka, Faculty of Tourism and Hospitality Management, Primorska 42, 51410 Opatija, Croatia 


\section{INTRODUCTION}

Artificial intelligence and service robots are in major presence in hotel industry in recent years. It is imperative for hotel industry to find new innovative sources for improving the service quality including digital technologies and AI. The term AI denotes behavior of a machine able to perform human tasks in the same way (Simmons, A. B., Chappell, S. G., 1988). As robots and AI are predicted to have a profound impact on the quality service and guest experience the goal of this article is to summarize the interaction between service quality, e-service quality and robotic service quality. The purpose of this study is to provide a comprehensive review of correlations between these concepts by analyzing relevant papers identified via Scopus, Web of Science, ResearchGate and Google Scholar. This paper presents the results of content analysis of the academic literature of robots, service quality, e-service quality and robotics service quality concepts in hotel industry. The findings underline the theoretical and practical discussions of robotic service quality toward human perceptions and attitudes in hotel industry.

\section{THORETICAL FRAMEWORK}

The application of new technologies such as robots, AI and service automation (RAISA), leads to an increasing number of studies in tourism and hospitality which are examining the deployment of robotic technology (Chan, A. P. H., Tung, V. W. S., 2019). Focused on the technological capacity to perform tasks, AI initially was envisioned as a way to combine perception, reasoning, and actuation focused more on algorithms (virtual), while robotics has been focused on mechanical functioning of AI (Belanche, D., et al., 2020). Artificial intelligence is associated with the ability of machines to understand and use human language and then continue to work on their own (Lukanova, G., Ilieva, G., 2019). The term "robot" originated from the Czech word robota and means forced labor and "has evolved in meaning from dumb machines that perform menial, repetitive tasks to the highly intelligent anthropomorphic robots of popular culture" (Lanfranco, A. R., et al., 2004). Robots are classified in two major categories: industrial robots and service robots where service robots (professional and personal service robots) are designed to support and service humans through physical and social interactions (International Organization for Standardization, 2012).

Table 1. Robots in Hotel Industry - definitions and aspects

\begin{tabular}{|l|l|c|}
\hline \multicolumn{1}{|c|}{ Author (Year) } & \multicolumn{1}{|c|}{ Definition } & $\begin{array}{c}\text { Google Scholar } \\
\text { Citation }\end{array}$ \\
\hline $\begin{array}{l}\text { Webster, C., } \\
\text { Ivanov, S. (2020) }\end{array}$ & $\begin{array}{l}\text { Robots are service agents that deliver services to } \\
\text { customers. }\end{array}$ & 1 \\
\hline $\begin{array}{l}\text { Wirtz, J., et al. } \\
(2018)\end{array}$ & $\begin{array}{l}\text { Service robots are system-based autonomous and } \\
\text { adaptable interfaces that interact, communicate and } \\
\text { deliver service to an organization's customers. }\end{array}$ & 762 \\
\hline $\begin{array}{l}\text { Murphy, J., et al. } \\
\text { (2017) }\end{array}$ & $\begin{array}{l}\text { Robots are relatively autonomous physical devices } \\
\text { capable of motion and performing a service. }\end{array}$ & 36 \\
\hline $\begin{array}{l}\text { Zalama, E., et al. } \\
\text { (2014) }\end{array}$ & $\begin{array}{l}\text { Robots in hotel industry are devices with certain } \\
\text { characteristics: embodiment, emotion, dialogue, } \\
\text { personality, human-oriented perception, environment } \\
\text { modeling, social learning and intentionality. }\end{array}$ & 36 \\
\hline
\end{tabular}




\begin{tabular}{|l|l|c|}
\hline $\begin{array}{l}\text { Chen, Y., Hu, H. } \\
(2013)\end{array}$ & $\begin{array}{l}\text { A robot is a perfect example of intelligent physical } \\
\text { devices. It is usually a system, which, by its appearance } \\
\text { or movements, conveys a sense that it has intent or } \\
\text { agency of its own. }\end{array}$ & 102 \\
\hline $\begin{array}{l}\text { Haidegger, T., et al. } \\
(2013)\end{array}$ & $\begin{array}{l}\text { A robot is an actuated mechanism programmable in } \\
\text { two or more axes with a degree of autonomy, moving } \\
\text { within its environment, to perform intended tasks. }\end{array}$ & 86 \\
\hline $\begin{array}{l}\text { Singer, P. W. } \\
(2009)\end{array}$ & $\begin{array}{l}\text { Robots are machines capable of carrying out complex } \\
\text { series of actions. }\end{array}$ & 3114 \\
\hline $\begin{array}{l}\text { Parasuraman, R., } \\
\text { Riley, V.(1997) }\end{array}$ & $\begin{array}{l}\text { Robot is an execution by a machine agent (usually a } \\
\text { computer) of a function that is carried out by a human. }\end{array}$ & \\
\hline
\end{tabular}

Source: Authors, 2020.

As stated in table 1, robots in hotel industry are mostly described as intelligent devices with a certain degree of autonomy, mobility, and sensory capabilities that allow them to perform intended tasks (Chen, Y., Hu, H., 2013; Murphy, J., et al., 2017). Following the technological innovations in hotel industry, robots are often seen as modern concepts of service quality in hotel industry (Ivanov, S. H., et al., 2017).

The development of service quality carried by robots can be described through different models of the service quality measurements. The first model for measuring service quality was developed by Grönroos in 1984. (Yarimoglu, E. K., 2015). Although service quality in hotel industry may underline a lot of different approaches, definitions mostly describe service quality as comparison of a customer's specific expectations regarding service (Berry, L. L., et al., 1988), perception after service consummation and degree of discrepancy between customers (Parasuraman, R., et al., 1988), competitive advantage to a business by establishing customer satisfaction and customer loyalty (Dedeoğlu, B. B., Demirer, H., 2015), long-term cognitive evaluation of business service offerings by customers (Zeithaml, V. A., et al., 2000), or overall impression of the relative inferiority/superiority of the organization and its service (Bitner, M. J., et al., 1994).

\subsection{SQ and e-SQ in hotel industry}

Lee, Y. C., et al. (2016) stated that most widely used instrument for measuring the service quality in various industries is a multi-item scale named SERVQUAL, developed by Parasuraman, A., et al. (1988) with five dimensions: reliability, assurance, responsiveness, tangibles and empathy. In addition, different measurements have been developed for service quality evaluation in hotel industry. Knutson, B., et al. (1990) developed LODGSERV, a consumers' expectations scale for measuring service quality in the hotel experience using five generic dimensions hypothesized by Parsuraman. Furthermore, Getty, J. M. and Thompson K.N. (1994) developed LODGQUAL scale to compare various properties existing under one management. HOLSERV scale is a shorter, more user-friendly version of SERVQUAL, developed to design service strategies that meet guests' expectations (Wong Ooi Mei, A., et al., 1999). Marković, S., and Raspor, S. (2010) developed a modified SERVQUAL scale to improve the crucial quality attributes and enhance service quality in hotel industry.

Service quality in evolution process with many important aspects of electronic commerce has influenced on the development of e-SQ. Starting with Information systems developed by DeLone, W. H., and McLean, E. R. (2002) through service commercialization, e-SQ may act as an intermediator from 
e-SQ to robot service quality. Taherdoost, H., and Hassan, A. (2012) defined e-SQ as the provision of interactional, content centered and electronic-based service over electronic network and a critical factor for successful implementation and decent performance of any business in electronic environment. Service quality concepts has been successfully applied in the electronic commerce practices in hotel industry but there are factors influencing the success of e-SQ versus generic service quality measurements. E-SQ was developed in the context of service provided through electronic, internet customer relations, while SERVQUAL was developed in the context of services provided through personal interaction between customers and service providers (Ladhari, R., 2010). The fourth stage of service evolution is predicted to be "a-service" with three features: service automation and humanrobot interaction, artificial intelligence and big data and smart travel experience (Leung, X. Y., 2019).

\subsection{Robotic service quality in hotel industry}

Parasuraman, A. (2000) developed Technology Readiness Index (TRI), a multiple-item scale to measure readiness to embrace new technologies including robots and AI. Many studies focus on software which implies a robotic service - rService defined as the service delivery channel by robot (Murphy, J., et al., 2019). Service robots can be physically or virtually present and that's the way of dividing the AI interaction between e-SQ to robotic service quality (Lu, L., et al., 2019).

A new challenge for hotel industry is how to integrate and proactively incorporate new technologies into their efforts to improve service quality through automation process (Law, R., Jogaratnam, G., 2005). Automation becomes part of value creation processes in the service sector which follow the complexity of hotel industry operations connected to guest experience and service quality, as well as by inherent characteristics of a robot, such as intelligence, mobility, and sensory abilities (Ivanov, S. H., et al., 2017). In terms of design, humanoid or non-humanoid appearance, cognitive-analytical tasks and emotional-social tasks, robots contribute to quality measurement (Wirtz, J., et al., 2018).

Table 2. Robotic service quality in hotel industry

\begin{tabular}{|c|c|c|c|c|c|c|}
\hline $\begin{array}{l}\text { Author } \\
\text { (Year) }\end{array}$ & Content & $\begin{array}{c}\text { Sample } \\
\text { (N) }\end{array}$ & $\begin{array}{l}\text { Data } \\
\text { analysis }\end{array}$ & Dimensions & $\begin{array}{c}\text { Reliability/ } \\
\text { Cronbach's } \\
\text { alpha }\end{array}$ & $\begin{array}{l}\text { Google } \\
\text { Scholar } \\
\text { Citation }\end{array}$ \\
\hline $\begin{array}{l}\text { Lu, L., et } \\
\text { al. (2019) }\end{array}$ & $\begin{array}{l}\text { Willingness } \\
\text { to integrate } \\
\text { service robots } \\
\text { into regular } \\
\text { service } \\
\text { transactions }\end{array}$ & 440 & EFA & 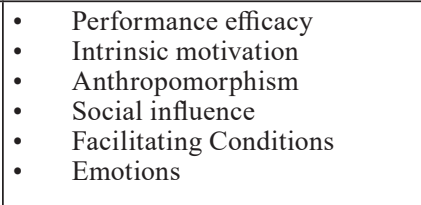 & $0.893-0.962$ & 32 \\
\hline $\begin{array}{l}\text { Ivanov, S., } \\
\text { Webster, } \\
\text { C. (2019) }\end{array}$ & $\begin{array}{l}\text { Attitudes } \\
\text { towards the } \\
\text { use of service } \\
\text { robots }\end{array}$ & 1003 & EFA & $\begin{array}{ll} & \text { Information provision } \\
& \text { Housekeeping } \\
& \text { Food, beverages and guidance } \\
\cdot & \text { Robot autonomy } \\
\cdot & \text { Personal services } \\
\cdot & \text { Entertainment } \\
\text { - } & \text { Bookings, payments and } \\
\text { documentation } \\
\text { First and last impression } \\
\end{array}$ & 0.932 & 26 \\
\hline $\begin{array}{l}\text { Li, J. J. et } \\
\text { al. (2019) }\end{array}$ & $\begin{array}{l}\text { Employees' } \\
\text { awareness } \\
\text { of robotics }\end{array}$ & 468 & $\begin{array}{l}\text { CFA, } \\
\text { SEM }\end{array}$ & \begin{tabular}{|ll} 
& AI and robotics awareness \\
- & Perceived organizational \\
- & support \\
Competitive psychological \\
climate \\
- & Turnover intention \\
\end{tabular} & - & 23 \\
\hline
\end{tabular}




\begin{tabular}{|c|c|c|c|c|c|c|}
\hline $\begin{array}{l}\text { Choi, Y. et } \\
\text { al. (2019) }\end{array}$ & $\begin{array}{l}\text { SQ perceptions } \\
\text { of robot } \\
\text { interaction } \\
\end{array}$ & 339 & EFA & \begin{tabular}{|ll}
- & Interaction quality \\
- & Outcome quality \\
- & Physical service \\
\end{tabular} & $0.780-0.930$ & 6 \\
\hline $\begin{array}{l}\text { Tussyadi- } \\
\text { ah, I. P., } \\
\text { Park, S. } \\
\text { (2018) }\end{array}$ & $\begin{array}{l}\text { Consumer } \\
\text { evaluation of } \\
\text { two different } \\
\text { hotel service } \\
\text { robots }\end{array}$ & 841 & $\begin{array}{l}\text { CFA, } \\
\text { PLS- } \\
\text { SEM }\end{array}$ & \begin{tabular}{|ll} 
- & Anthropomorphism \\
- & Animacy \\
- & Likeability \\
- & Perceived intelligence \\
- & Perceived security \\
- & Importance \\
\end{tabular} & $0.835-0.779$ & 63 \\
\hline $\begin{array}{l}\text { Stock, } \\
\text { R. M., } \\
\text { Merkle, M. } \\
(2017)\end{array}$ & $\begin{array}{l}\text { Human robot } \\
\text { acceptance } \\
\text { during service } \\
\text { encounters }\end{array}$ & 82 & t-test & $\begin{array}{ll}- & \text { Functional component } \\
\text { - } & \text { Informational component } \\
& \text { Relational component }\end{array}$ & - & 19 \\
\hline
\end{tabular}

Note: CFA - confirmatory factor analysis, EFA - exploratory factor analysis, SEM - structural equation measurement, PLS-SEM - partial least squares path modeling of structural equation measurement

Source: Authors, 2020.

Table 2 presents the most relevant robotic service quality measurements in the last 4 years in terms of willingness to use robotics by hotels, employee perceptions and attitudes of potential guests. Presented robotic SQ scale measurements mostly have been carried out from standard SQ measurements adapted to robots. Studies from 2019 are more reflected to the human robot interaction while others are mainly referring to functional components of robots in SQ. The factor analysis used in all researches indicate that intrinsic motivation, social influence, and emotions are more important than other dimensions for robotic driven hotel services. Information provision, housekeeping activities and processing bookings, are most appropriate areas of robot application in hotel. Choi, Y., et al. (2019) defined that people treat robots as social actors whose performance could be evaluated using service quality dimensions. Robotic service quality measurement scales are able to provide a know how model to the view of new hotel SQ practical implications.

\section{CONCLUSION}

Theoretically, this study presents the definitions and measurement scales of traditional service quality to robotic service quality. Previous studies conducted in hotel industry identified different outcomes with regard to the interpretation of dimensions used to contribute the measurement context of the service quality development: SQ - e-SQ - robotic service quality. Most common factors of perceived SQ to AI and robotic service quality development in hotel industry appears to be "reliability" and "tangibles". Key dimensions characterizing hotel integration artificial intelligence and service robots into regular hotel service transactions are developed by measurement scales of people attitudes toward robots, consumer evaluation and employees' awareness. Service robots' abilities designed for hospitality firms still need to be improved to meet the demand of customers (Qiu, H., et al., 2020).

The analysis was based only on researches linking the study of robots in hotel industry in largest databases referring issues from a more general perspective. The correlation between researched frames could be in further research focus among strong and widespread inter-disciplinary research collaborations based on quantitative research design. 


\section{REFERENCES}

Belanche, D., Casaló, L. V., Flavián, C., \& Schepers, J. (2020). Service robot implementation: a theoretical framework and research agenda. The Service Industries Journal, 40(3-4), 203225. https://doi.org/10.1080/02642069.2019.1672666

Berry, L. L., Parasuraman, A., \& Zeithaml, V. A. (1988). The service-quality puzzle. Business horizons, 31(5), 35-43.

Bitner, M. J., Booms, B.H. \& Mohr, L.A. (1994). Critical Service Encounters: The Employee Viewpoint. Journal of Marketing, 58(4), 95-106. https://doi.org/10.1177/002224299405800408

Chan, A. P. H., \& Tung, V. W. S. (2019). Examining the effects of robotic service on brand experience: the moderating role of hotel segment. Journal of Travel \& Tourism Marketing, 36(4), 458-468. https://doi.org/10.1080/10548408.2019.1568953

Chen, Y., \& Hu, H. (2013). Internet of intelligent things and robot as a service. Simulation Modelling Practice and Theory, 34, 159-171. https://doi.org/10.1016/j.simpat.2012.03.006

Choi, Y., Choi, M., Oh, M., \& Kim, S. (2019). Service robots in hotels: understanding the service quality perceptions of human-robot interaction. Journal of Hospitality Marketing \& Management, 1-23. https://doi.org/10.1080/19368623.2020.1703871

Dedeoğlu, B. B., \& Demirer, H. (2015). Differences in service quality perceptions of stakeholders in the hotel industry. International Journal of Contemporary Hospitality Management. 27(1), 130-146. https://doi.org/10.1108/IJCHM-08-2013-0350

DeLone, W. H. \& McLean, E. R. (2002). Information systems success revisited. Proceedings of the 35th Annual Hawaii International Conference on System Sciences, Big Island, HI. 2966-2976, doi: 10.1109/HICSS.2002.994345.

Getty J.M. \& Thompson, K.N. (1994). A procedure for scaling perceptions of lodging quality. Hospitality Research Journal, 18(2), 75-96. https://doi.org/10.1177/109634809401800206

Haidegger, T., Barreto, M., Goncalves, P., Habib, M. K., Ragavan, S. K. V., Li, H., Vaccarella, A., Perrone, R. \& Prestes, E. (2013). Applied ontologies and standards for service robots. Robotics and Autonomous Systems, 61, 1215-1223. https://doi.org/10.1016/j.robot.2013.05.008

International Federation of Robotics (IFR) (2012). Service robot, provisional definition of service robots, visited June 23, 2020. http://www.ifr.org/service-robots/

Ivanov, S. H., Webster, C., \& Berezina, K. (2017). Adoption of robots and service automation by tourism and hospitality companies. Revista Turismo \& Desenvolvimento, 27(28), 1501-1517.

Ivanov, S. H., \& Webster, C. (2019). Perceived appropriateness and intention to use service robots in tourism. In Pesonen, J., \& Neidhardt, J. (Eds.) Information and Communication Technologies in Tourism 2019, (pp. 237-248) Cyprus: Proceedings of the International Conference in Nicosia.

Ivanov, S., Gretzel, U., Berezina, K., Sigala, M., \& Webster, C. (2019). Progress on robotics in hospitality and tourism: a review of the literature. Journal of Hospitality and Tourism Technology. 10(4), 489-521. https://doi.org/10.1108/JHTT-08-2018-0087

Ivanov, S., Webster, C., \& Garenko, A. (2018). Young Russian adults' attitudes towards the potential use of robots in hotels. Technology in Society, 55, 24-32. https://doi.org/10.1016/j. techsoc.2018.06.004

Knutson, B., Stevens, P., Wullaert, C., Patton, M., \& Yokoyama, F. (1990). LODGSERV: A service quality index for the lodging industry. Hospitality Research Journal, 14(2), 277-284. https:// doi.org/10.1177/109634809001400230

Ladhari, R. (2010). Developing e-service quality scales: A literature review. Journal of Retailing and Consumer Services, 17(6), 464-477. https://doi.org/10.1016/j.jretconser.2010.06.003

Lanfranco, A. R., Castellanos, A. E., Desai, J. P., \& Meyers, W. C. (2004). Robotic surgery: a current perspective. Annals of surgery, 239(1), 14. doi: 10.1097/01.sla.0000103020.19595.7d. 
Law, R., \& Jogaratnam, G. (2005). A study of hotel information technology applications. International Journal of Contemporary Hospitality Management. 17(2), 170-180. https://doi. org/10.1108/09596110510582369

Lee, Y. C., Wang, Y. C., Chien, C. H., Wu, C. H., Lu, S. C., Tsai, S. B., \& Dong, W. (2016). Applying revised gap analysis model in measuring hotel service quality. SpringerPlus, 5(1), 1191. https://doi.org/10.1186/s40064-016-2823-z

Leung, X. Y. (2019). Technology-enabled service evolution in tourism: a perspective article. Tourism Review, 75(1), 279-282. https://doi.org/10.1108/TR-06-2019-0229

Li, J. J., Bonn, M. A., \& Ye, B. H. (2019). Hotel employee's artificial intelligence and robotics awareness and its impact on turnover intention: The moderating roles of perceived organizational support and competitive psychological climate. Tourism Management, 73, 172-181. https://doi.org/10.1016/j.tourman.2019.02.006

Lu, L., Cai, R., \& Gursoy, D. (2019). Developing and validating a service robot integration willingness scale. International Journal of Hospitality Management, 80, 36-51. https://doi. org/10.1016/j.ijhm.2019.01.005

Lukanova, G., \& Ilieva, G. (2019), Robots, Artificial Intelligence, and Service Automation in Hotels. In Ivanov, S. and Webster, C. (Ed.) Robots, Artificial Intelligence, and Service Automation in Travel, Tourism and Hospitality (pp. 157-183). London: Emerald Publishing Limited. https://doi.org/10.1108/978-1-78756-687-320191009

Markovic, S., Raspor, S. (2010). Measuring Perceived Service Quality Using SERVQUAL: A Case Study of the Croatian Hotel Industry. Management, 5(3).

Wong Ooi Mei, A., Dean, A. M. \& White, C. J. (1999). Analysing service quality in the hospitality industry. Managing Service Quality: An International Journal, 9(2), 136-143. https://doi. org/10.1108/09604529910257920

Murphy, J., Gretzel, U., \& Pesonen, J. (2019). Marketing robot services in hospitality and tourism: the role of anthropomorphism. Journal of Travel \& Tourism Marketing, 36(7), 784-795. https://doi.org/10.1080/10548408.2019.1571983

Murphy, J., Hofacker, C., \& Gretzel, U. (2017). Dawning of the age of robots in hospitality and tourism: Challenges for teaching and research. European Journal of Tourism Research, 15, 104-111.

Parasuraman, A. (2000). Technology Readiness Index (TRI) a multiple-item scale to measure readiness to embrace new technologies. Journal of service research, 2(4), 307-320. https:// doi.org/10.1177/109467050024001

Parasuraman, A., Zeithaml, V. A., \& Berry, L. L. (1988). Servqual: A multiple-item scale for measuring consumer perceptions of Service Quality. Journal of retailing, 64(1), 12.

Parasuraman, R., \& Riley, V. (1997). Humans and automation: Use, misuse, disuse, abuse. Human factors, 39(2), 230-253.

Qiu, H., Li, M., Shu, B., \& Bai, B. (2020). Enhancing hospitality experience with service robots: The mediating role of rapport building. Journal of Hospitality Marketing \& Management, 29(3), 247-268. https://doi.org/10.1080/19368623.2019.1645073

Simmons, A. B., \& Chappell, S. G. (1988). Artificial intelligence-definition and practice. IEEE Journal of Oceanic Engineering, 13(2), 14-42.

Singer, P. W. (2009). Wired for war: The robotics revolution and conflict in the 21st century, New York: Penguin.

Stock, R. M., \& Merkle, M. (2017). A service Robot Acceptance Model: User acceptance of humanoid robots during service encounters. In 2017 IEEE International Conference on Pervasive Computing and Communications Workshops (pp. 339-344). IEEE. DOI: 10.1109/ PERCOMW.2017.7917585 
Taherdoost, H., \& Hassan, A. (2020). Development of an E-Service Quality Model (eSQM) to Assess the Quality of E-Service. In Strategies and Tools for Managing Connected Consumers (pp. 177-207). IGI Global. DOI: 10.4018/978-1-5225-9697-4.ch011.

Tussyadiah, I. P., \& Park, S. (2018). Consumer evaluation of hotel service robots. In B. Stangl \& J. Pesonen (Eds.), Information and communication technologies in tourism (pp. 308-320). Cham: Springer. https://doi.org/10.1007/978-3-319-72923-7_24

Webster, C., \& Ivanov, S. (2020). Robots in travel, tourism and hospitality: Key findings from a global study. Varna: Zangador.

Wirtz, J., Patterson, P. G., Kunz, W. H., Gruber, T., Lu, V. N., Paluch, S., \& Martins, A. (2018). Brave new world: service robots in the frontline. Journal of Service Management. 29(5), 907-93. https://doi.org/10.1108/JOSM-04-2018-0119

Yarimoglu, E. K. (2015). A Review of Service and E-Service Quality Measurements: Previous Literature and Extension. Journal of Economic \& Social Studies (JECOSS), 5(1).

Zalama, E., Garcia-Bermego, J. G., Marcos, S., Dominguez, S., Feliz, R., Pinillos, R. \& Lopez, J. (2014). Sacarino, a Service Robot in a Hotel Environment. In: Armada M., Sanfeliu A., \& Ferre M. (Eds), ROBOT2013: First Iberian Robotics Conference. Advances in Intelligent Systems and Computing, 253. Springer, Cham https://doi.org/10.1007/978-3-319-03653-3_1

Zeithaml, V. A., Parasuraman, A., \& Malhotra, A. (2000). A conceptual framework for understanding e-service quality: implications for future research and managerial practice. Marketing Science Institute. 